\title{
Accursed Play: the economic imaginary of early game studies
}

Games and Culture: a journal of interactive media (in press: 2018).

Seth Giddings, Winchester School of Art, University of Southampton s.giddings@soton.ac.uk

\begin{abstract}
Revisiting early critical responses to computer and videogames as a cultural form - before the establishment of games studies as an academic field in the early 2000s - reveals a consistent fascination with games as economic phenomena. Not just as a new commercial competitor in the established popular media marketplace, but as models of economies in their own right, models that mesh with player's everyday lives, constraining, facilitating and forming gameplay. This article will identify and explore some of the most salient themes and phenomena in this early games scholarship and will follow them through subsequent enquiry into games as economies either isomorphic with the systems of consumer capitalism and neoliberalism from which they issue, or metamorphic - phantasmagorical or ironic inversions of prevailing social and industrial conditions.
\end{abstract}

\section{Keywords}

Game studies, videogame industry, videogames as economic form, neoliberalism, economic simulation, phantasmagoria, Georges Bataille

\section{Introduction}

Since its inception in the early 2000s, game studies has generated a rich set of critical resources on the economic dimensions of digital game design, production and play, from studies of the games industry (Alvisi 2006, Kerr 2005, 2016), the business models that drive various game formats (Nieborg 2015), game consumption and audiences (Shaw, 2014, Taylor, 2006), to the central role games and playful media now take in the global cultural economy (Dyer-Witheford \& de Peuter 
2009). However the study of videogames predates game studies. Early critical attention to computer and videogames in the 1980s and 1990s is often characterised by a fascination with games as economic phenomena (e.g. Bernstein 1991, Fiske and Watts 1985, Stallabrass 1993). For some, the novelty and potential of this new technocultural form lay in its imbrication of information technology, new everyday behaviours, new economic and business models, with its players evidence of emergent, disquieting, subject positions. Arcade games and domestic computer games were more than just a new commercial competitor in the longer established popular media entertainment marketplace, rather they were seen as models of economies in their own right, their virtual worlds both simulating (more or less accurately) the logic of late capitalism and meshing in more or less complicated ways - through play - with player's everyday lives and sense of self. Thus the relationship between the virtual economics of the gameworld and the actual world of a capitalist economy undergoing rapid restructuring are connected through both computer technology and an intensification of consumption-driven growth. This article will identify and explore some of the most salient themes and phenomena in this early games scholarship and will follow them to open up and recast subsequent enquiry into games as economies. If games themselves are virtual economies what is valued, and what exchanged? And in what ways might these ludic economies - designed for play - exceed or suggest alternatives to late capitalist and neoliberal formations?

Throughout I will trace the ambiguous relationships between endogenous (internal to the game system) and exogenous (external to games) ludic economies. As the theme of this special issue is modes or systems of exchange and value alternative to neoliberalism and consumer capitalism, this article will suggest other, older, (stranger) modes of value and exchange, modes that animate digital games and digital culture. These modes can help us to recognise two linked critical and creative approaches. The first is the identification and analysis of disruptive ludic economies within already 
existing game cultures. And the second is the imagining and designing of new game systems and experiences - as heuristic devices for thinking up, or across, economic and social systems more generally. The article will conclude with suggestions that game economies might be understood as phantasmagorical in a more positive and generative sense - as liminoid, nonsensical and strange, and hence as a seedbed for new formations and resources for behaving and imagining differently within and against the prevailing neoliberal cultural economy.

\section{The economics of play and games}

What then is the 'economic' in ludic culture, and what concepts might help open up what we think of as the economics of games, and what we think of as economies in themselves? What is exchanged, and what is valued? What are the needs to be sated, the scarcities to be overcome, the abundance and the waste? And if, as I will argue, games themselves are understood as microcosmic economies, what is their relationship to the modes of production and economically-driven ecologies of consumption within which they are produced, distributed and played - from the global entertainment economy to everyday consumer culture? The product of dominant economic forces, do games realize and reproduce the values, behaviours and subject positions that smooth the passage of these forces in everyday play?

The gameplay of many, if not most, popular games is structured around the accumulation and expenditure of virtual goods or currency, from Mario's stars and Sonic's rings through The Sims' simoleons and The Legend of Zelda's rupees, to the contemporary interplay between virtual and actual currency in MMOs and mobile freemium games. The early critical attention to computer games as economic phenomena evinces a tension between the assumption that they more or less directly reproduce dominant value systems - consumerism in particular - or even enforce them more strongly than other popular commercial media. It also suggests ways in which their images, 
value systems and player behaviours might challenge, exceed or invert late capitalist and consumerist frames of knowledge and behaviour.

\section{Economic allegories}

As well as their evident burgeoning significance as a lucrative industry in the late 1980s and early 1990s, games seemed to a number of commentators to epitomize and symbolize new and significant economic, industrial and historical cultural configurations. In their interaction and immersion, games represented a new intensification of consumer media culture, one that was

linked both materially and symbolically to the information revolution and its reconfiguration of late capitalism. The significance of games was found in the interplay between the novelty (as screen media) of their status as software and code and their position and workings within the late capitalist or consumerist economy that spawned them. These range from playful readings of games as allegories of consumer culture to neo-Marxist readings of the economics and semiotics of computer games as models of, realisations of - or even training for - capitalist relationships at both the micro-level of the playing / consuming subject and the macro-level of fundamental shifts in capitalism as a historical and global system. For example, Steven Poole, in his book Trigger Happy: the inner life of videogames (2001), conducted a playfully serious semiotic analysis of Pac-Man as an allegory of consumerist subjectivity, a 'parable of late capitalism' (Poole 2001,189). Noting that the game's designer Toru Iwatani himself said that the Pac-Man character is 'the personification of eating', Poole argues that the game is 'at once infantile and politically loaded' (Poole 2001, 192), conflating the game's drive to consume for survival, the individual act of eating, and late-twentieth century consumer capitalism:

For Pac-Man, consumption cannot end; no conceivable quantity of dots is enough. He will continue to search them out and eat them until he dies (Poole 2001, 192-3). 
Some years earlier, the art historian Julian Stallabrass, horrified by the videogames of the late 1980s and early 1990s, depicted the new virtual world they heralded as one of the triumph of technology and commodification. Drawing on concepts from Frankfurt School critiques of the capitalist cultural economies, he saw in the scrolling worlds and sprites of the 8 and 16 bit era at once the allegorisation of late capitalism and its absolute colonization of everyday media life:

emptied of all materiality, use-value and exchange-value are no longer opposed, but are collapsed into an ideal unity. The game world appears as a perfect, Utopian market, in which bright, clear-cut, even glowing commodities are, for once, all that they seem to be (Stallabrass 1993).

Here then, digital culture effects the hyper-charging of phantasmagorical social relations diagnosed by Benjamin and Adorno in the 1930s and 40s. The veils of Marx's commodity fetishism, the illusory relationships between objects that mask the real but invisible workings of capital and social power - are now re-invigorated by the new intangible but highly operational depths of computer code and networks. Computer games are at once a lucrative product of late capitalist media and consumer culture, and allegories of it. Stallabrass adopts the notion of phantasmagoria from Theodor Adorno's critique of capitalist culture, but it derives from the early chapters of Capital, where Marx vividly depicts the commodity form as a gothic vision of reality (the new economic relationships of mercantile and industrial capitalism) hidden behind spectral visions of material objects and resources coming to life and taking on their own value and spirit - like the spirit medium's trick of 'table-turning', shrouding the economic realities that are the actual animating force (Marx, 1990 [1867]). For Stallabrass the computer game updates the commodity form into a science fiction nightmare. The games look like commodities (shiny, novel, depthless), are structured 
as economic exchange, are allegories of capitalist culture and relations, players are positioned as ideal liberal individuals, but individuals at once constructed from quantitative attributes and, in their machine-driven bodily actions, reified in a grotesque parody of manual work.

Aside from its pre-game studies historical interest and an entertainingly lurid dystopian tone, why is this dismissive vision of game-playing worthy of attention to contemporary game scholars? It paints a vivid picture of the computer game as an economy - a microcosmic allegory of, at once, capitalism, the commodity form, and the reification of the worker's body under capitalist conditions. Video games here are at once a mirror of, and integral component within, late capitalism's emerging digital networks, a reduction of the complexity and drives of economic activity to a solid-state circuit of numerical exchange:

A tyranny of number is the founding principle of these games and to play successfully is to emulate the qualities of the machine: reaction, regulation and economy in discrete, repetitive acts (Stallabrass 1993).

A decade later, with console gaming now a dominant and familiar sector of the global cultural economy, Stephen Kline, Nick Dyer-Witheford and Grieg de Peuter addressed digital games in a similar critical vein, albeit with a substantially more robust and nuanced attention to the economies of the games industry and the form of particular games. Games, they argue, are the 'ideal commodity' of post-Fordist capitalism (Kline et al 2003, 62), the centre of an infernal Venn diagram of global promotional and marketing strategies, postmodernist culture, and digital and interactive technological regimes - which together make up an 'accumulatory regime' the authors call, halfplayfully - Sim Capital' (Kline et al 2003, 278). The acknowledgement of videogames' central position within late twentieth and early twenty-first century technological, economic and cultural 
landscapes is uncontroversial. For the purposes of this article however I am interested in the ways in which critical approaches to economic dimensions of games and gameplay understand the relationships between the macro level of the global economy and the micro level of everyday behaviour, thought and subject positions in play. For Stallabrass in the early 1990s and Kline et al in the early 2000s, the playing of videogames directly and dangerously reproduced the dominant economic forces and their ideological corollaries in and through gameplay. Moreover, for them this reproduction is effected in ways more far-reaching and powerful than the mass media around which the Frankfurt School developed their critique. Noting the uniquely interactive and performative behaviours brought to screen media consumption by videogames, each of these critiques imply that the ideological impact is therefore more powerful, more absolute than in television or the cinema. For Stallabrass the immersive pull of ever-more realistic games leaves a rapidly dwindling space for critical reflection in everyday play. For Kline et al the simulational form of games, The Sims in particular, is inseparable from other more instrumental forms of interactive digital media, notably training simulations. Thus,

Increased reliance on simulations both as work tools and as consumer commodities, escalating surveillance and synergistic management of segmented markets, and the cultivation of an increasingly symbiotic relation between production and consumption is mediated through the feedback loops created by ever more sophisticated digital media and virtual technologies. As the virtual Sims are to the Sim player, so the Sim Player is to Sim Capital. Playing The Sims is, in short, a process in which the player takes up - but could also subvert symbolically - digital capital and learns to elaborate its logic - a logic to which she or he is already subject (Kline et al 2003, 279). 
They note the industrial connections between simulations as training tools and simulations as gameworlds for entertainment, extrapolating that their functions are the same: 'The idea that military simulations provide training for soldiers is familiar; what The Sims does is provide civilian simulator training for yuppies' (Kline et al 2003, 276)i.

\section{Beyond the allegorical and the isomorphic: the strangeness of simulated economies}

These accounts model the relationship between the technocultural form of the videogame and the global cultural-economic environment from which it issues as at once behaviourally, materially and symbolically isomorphic. That is, the acquistional, information-capital relations that drive the global economy at large, and the micro-circuits of information circulation, subject construction, and virtual commodity acquisition in the games themselves are identical: the Sims player, this argument runs, is trained for Sim Capital as he or she trains their Sims. It is precisely these intimate and material circuits between global capital, technoculture and everyday moments of play that makes the videogame such a fascinating object for the study of contemporary technocultural political economy. However I will suggest that left pessimist assumptions of isomorphism are only partial in their attention to videogame economies, both micro and macro. Close attention to particular games' constitution of dynamic relationships of value and exchange, and to their instantiation in moments of play, quickly troubles assumptions that videogames and play are direct microcosmic models of the neoliberal forces that generate them. I argue instead that the endogenous economics of games and their articulation with exogenous economics - is more ambivalent and generative than pessimist accounts would allow.

To explain this approach, I will stick with The Sims and related resource management games. The Sims franchise is unapologetic in its appeal to consumer behaviour and culture: the player directs the game's characters to work, accumulate, consume, to develop their selves within neoliberal logic 
of conspicuous consumption, and cultured leisure, all within a simulation of an affluent North American suburban environment. But if we persist with the notion that videogames are economic in form (as relationships of value and exchange, dynamically motivated through algorithms and variables) before they explicitly model or depict particular economic systems or behaviour (everyday consumption, consumer capitalism, etc.) then what is the relationship between the economic drives and demands and systems of the games as software via the symbolic layer to actual world ideas and behaviour? The briefest glance at a videogame simulation of any cultural or economic behaviour reveals they are by no means straightforwardly isomorphic. All simulation design necessitates a fundamental process of abstraction to simplify the infinite complexity of any actual system into a quantified model with clearly defined variables and relationships (Giddings 2014b). A significant challenge of playing The Sims is to grasp the extent to which the code-driven actions of the virtual people depart from common-sense expectations of actual behaviour (see Giddings and Kennedy 2006, 140-141). Add to this the fact that videogames are rarely, if ever, serious models of actual economies or realistic training for everyday life and consumption: they are designed for entertainment, offering the player challenges and withholding or deferring rewards for ludic ends. For instance, if a Sims player does not follow some key restrictions in the design and layout of their house, there is a strong chance that the virtual occupants will take too long to get ready in the morning, will miss their lift to work, and thus lose their job. Driven by deliberate and designed flexibility, the necessary abstractions of software models (and the emergent anti-realities these tend to facilitate), and an exploratory or even mischievous approach by some players, microeconomies follow trajectories away from the actual world systems they ostensibly model, and towards new nonsensical or excessive systems. Attention to each of these - the abstractive and emergent tendencies of simulations and the contingent practices of everyday play - renders any assumption of a straightforward or isomorphic relationship between a simulated economy and the actual economy it purports to model. Small-scale ethnographic studies of resource management 
game play often describe phantasmagorical events emerging from the collusion of the games' 'sandbox' openness and individual players' moral sensibilities or moment-by-moment flights of imagination (e.g. Giddings 2014a, Ito 1996, Stevens et al 2008). And, as I will explain later, game elements such as cheat codes, and game systems in general, could be more accurately described as metamorphic, constituted by economic drives and effects quite distinct from the late capitalist forces depicted or allegorized in games' dramatic worlds.

What then are the characteristics of endogenous ludic economies - the videogame as a virtual micro-economy? Importantly for this analysis, the underlying structure and process of all digital games is an economy of sorts, regardless of the thematic and symbolic dimensions of the game as depicted on the screen. That is, not all games explicitly simulate actual world economies, but all games are fundamentally economic: as processual systems they determine and distribute resources, and establish dynamic relations of value and exchange between elements. Designed on a spreadsheet, SimCity games' parks, fire stations, sewage outlets etc. are rigidly quantified variables and the relationships between levels of taxation, growth, public satisfaction and so on are mathematically determined for challenging gameplay rather than fidelity to any particular historical economic model or system.

So, games are in and of themselves nothing if not economies. All digital games set up systems of value, exchange, accumulation and expenditure. SimCity might be termed a 'resource management' game, and its theme and motive explicitly presented as economic, but many - if not all - games are predicated to some extent on the management of resources by both software and player. The challenge of an FPS or adventure game is as much driven by the seeking out, accumulation and exchange or expenditure of resources as by hand-eye coordination and skill. The resources in the Tomb Raider or Resident Evil games may be presented as ammunition and health, rather than 
currency, but are clearly more or less abstract, valued and expended within an algorithmic economy.

But what are the implications for game culture at large of the identification and emphasis of these nested economies? What are the relationships between the economic systems of software, in-game diegetic accumulation and exchange, through to the actual worlds of everyday play and global consumption? Attention to simulacral economies endogenous to game worlds adds to the understanding of the videogame as a distinct media form (and its possibilities) but also as media objects that plug materially and semiotically into everyday behaviour and ideas about the everyday (and their possibilities). At the very least this approach renders problematic assumptions that a videogame's diegetic economy is straightforwardly mimetic or isomorphic - a more or less ideologically-driven modeling of, or 'training' for, actual economic relationships and systems. As I

argue later, the workings of the software economy on the diegetic world and the playing out of both in everyday life are profoundly and necessarily metamorphic. In countering assumptions of isomorphism I do not mean to assert that relationships between these systems do not exist, nor that they are necessarily fully transformed. Like the tadpole changing to a frog, in any metamorphosis some characteristics and organs persist, some are adapted, and some disappear to be replaced by new ones.

\section{The inverted political economy of arcades}

An early but informative example of the exploration of ludic economies that suggests a more nuanced metamorphic relationship between games, player behaviour and can be found in critical responses to videogame arcades in the early to mid 1980s (Fiske and Watts, 1985). Though still a marginal, emergent digital culture - not yet the 'ideal commodity' - of the 1990s, the form of, and play with, arcade machines suggested a cultural-economic imaginary of the emerging information 
revolution and its contradictory social effects. Pinball arcades had long been a source of patrician concern for the trajectory of youth culture, and this moral opprobrium was amplified and extended by a vision of computer game play in arcades as, like pinball and fruit machines, a wasteful distraction of youth from education and work, but also ambiguously connected to modern, or emergent, economic and technological forces. The vivid newness of the transfixed and twitching arcade players, the contrast between bright colourful screens and shadowy environment seemed to epitomise fears for the future of youth in a rapidly changing technological environment. That the players had to provide a constant supply of coins to perpetuate their play brought the economic dimension of this new medium to the fore - an uneasy collision of 'wasteful' activity with a highly lucrative new extension of a consumer capitalist entertainment business. The 'pay to play' business model of the arcade coin-op machine was quite different to the economics of broadcast and other popular entertainment media such as TV, cinema, recorded music, and radio. These relied on either a one-off purchase of the media object or experience (cinema screening, vinyl record, book) or indirect payment via advertising or license fee. This was a business model drawn from the peripheral geographies of the arcade, pier and theme park and the mechanical technoculture of the pinball table and fruit machine.

In particular, the coin-op videogames brought to popular media culture - and hyper-charged - the temporal economics of pinball, so that payment, media experience, and player skill were tightly connected and articulated in the arcade machine. Rather than paying a fixed amount for a media artefact, the duration of the pinball and Space Invaders experience depended on the interplay of mechanical contingency and player skill. Simply, the better the player the less he or she spent. Observing Australian arcades in the early 1980s, John Fiske and Jon Watts theorised technology, play, and time as they intersected with entertainment, cultural economy and the specificities of the computer game as a screen medium, tracing a set of significant contradictions and 'inversions' 
within arcade play and anxious responses to it. Arcade play looked something like work as the player stood at a machine for lengthy periods of time as if at a factory assembly line, but was flamboyantly non-productive. The players' rapt attention to the cathode ray screen was reminiscent too of domestic leisure and television, and hence all the associated contemporaneous concerns for the fate of young people in a commercial media culture. On the one hand videogames appeared in arcades, spaces already marked as suspect - wasteful, addictive, potentially delinquent - and on the other as the 'other' to the acceptable and disciplined expenditure of energy through economically unproductive competition: the restricted leisure economies of sport.

For Fiske and Watts the 'machine' here is an ambivalent metonym for both industrial work (in the late 1970s and early 1980s still regarded as predominantly factory-based manufacturing) and for the cultures of media consumption (particularly television). In the arcade's inversion of the timedriven logic of capitalist production,

the machinist works not with the machine, but against it [...] The better the machinist, the less he pays, and the lower the profit of the owner. This must be a unique phenomenon in capitalism, when the skill and speed of the machinist results in lower profits for the owner (Fiske \& Watts 1985, 93).

The player pays to 'work', feeding the slot with coins, thus alienated work is inverted - symbolically at least, the 'human/machine interaction' put to the service of adolescent identity production that feeds into and from capitalist media culture but resists the identity roles offered by the world of adult work. Coin-op play then was a 'time for self-generated semiosis, a time to produce meanings of self and for the self that the world of work denies' (Fiske \& Watts 1985, 93). The articulation of 
time, attention and money has persisted as a crucial and non-metaphorical dimension in the economic nature of game play in today's app and attention-driven cultural economy.

Over thirty years later, with hindsight on decades of industrial, economic and technological change, we read the arcade machinist differently. Where Fiske and Watts saw an ironic inversion of the assembly line machinist, we now see a more upright reflection of the now-dominant technics of work that were only just emerging in the 1980s. These players were not only gazing at sort-of TV screens, but also at the terminals and interfaces of information and networked communication: the imminent future of a digital economy in which the same machines serve - and blur - work and leisure. Thus, from the perspective of the twenty-first century Carly Kocurek notes that arcade machines not only popularised and normalised computers, they served a dual didactic role for late capitalism. They both prepared players for roles in production - within the emerging white-collar service sector and 'as investor players in an increasingly deregulated marketplace' (Kocurek 2012,193), whilst in the sphere of consumption, '[a]rcades became a crash course in spending for youths who had not yet passed into the economic order by joining the labor force' (Kocurek 2012, 194). Like Fiske and Watts, she notes important inversions of cultural and economic value in this prehistory of the information society:

Video games' didactic function made them suspect as they carried an emergent set of values and practices at odds with existing cultural norms and ideals. The economic practices of gaming coupled with the focus on individual competition put the games at odds with modernist economic and labor practices (Kocurek 2012,193).

Of course, the rise of neoliberal economics and consumer capitalism in the 1980s did not replace work with consumption, and playful digital culture continued - and continues today - to prefigure 
and allegorise new modes of playful work and industrial play, in the participatory cultures and affective labour of the internet and the new forms of in-game work found in MMOs. Joyce Goggin has noted the ironic return of industrial labour in online gameworlds, in the forms of gold-farming and grinding:

in what has otherwise become a finance-based, post-production economy, the practice of grinding returns workers to a Fordist labor model, wherein production follows a preestablished pattern, and wherein each new virtual product requires an equal amount of time and resources to produce over and over again (Goggin 2009: 133).

This curious eruption of actual, productive and lucrative work within the ludic virtual is an ironic counter to the abiding dismissal of videogame culture as all in all a waste, and in particular a waste of time. From the arcades to bedroom consoles to MMOs and MOBAs, parents, educators, policymakers and cultural commentators have vilified videogame play as shouldering out other, more edifying, healthy, imaginative and intellectually engaging activities from educational software to body and mind enhancing outdoor exercise. Within late capitalist leisure there is a clear moral preference for more productive, work-like play.

\section{Play, work, and waste}

So videogame play in the arcades and the home in the 1980s, whilst fully part of a new technological consumer culture, seemed at the same time unstable or potentially disruptive in its unproductive, compelling, wasteful attractions. The two accounts of the cultural economy of arcades outlined above are, I argue, tentative examples of metamorphic relationships between videogames as media objects, videogame play as embodied and situated behaviour, and the cultural economics of late capitalism at large. A key unsettling factor that disrupts the smooth isomorphic 
relays between virtual worlds of ideal consumption and allegorised commodities, players' expenditure of money and attention and their capitulation to the accumulative and subjective demands of neoliberal cultural economy, is the turbulent role of play itself. At its most simple, as Fiske and Watts note, the tension between work and play has always been a disruptive force for capitalist organisation and its moral structures. Nineteenth century work patterns regulated play (and all 'non-productive' cultural activities) to tightly constrained breaks and holidays. In a consumer culture play is vital to key sectors of the economy from media and entertainment to leisure and tourism, not least at present, with celebratory predictions (and critical responses to) notions of gamification, a 'ludic century' and the 'ludification of culture' in general (Frissen et al 2015, Fuchs et al 2014, Wark 2013, Zimmerman and Chaplin 2013). Yet, as we've seen and continue to see, the nurturing or training of future consumers brings with it anxieties about excessive or wasteful play and consumption, a fundamental contradiction between economically useful consumption and morally suspect indulgence and passivity. For Marxian thinking, this contradiction is historically specific to capitalism. The accumulative demands and hence moral and cultural superstructure from mercantile capitalism through the factory system to consumer culture have re-worked play into its modern forms of consumption, and through the monetisation and disciplining of pre-capitalist folk culture into privatised hobbies, commercialised leisure and morally validated sport.

In a few short paragraphs in article on videogames written in the late 1980s, Charles Bernstein hinted at some significant connections between the economies of work and play along these lines of waste and excess. Through a brief reference to the French Surrealist philosopher Georges Bataille, Bernstein considers game culture within a much wider cultural and historical frame. 
In a society in which the desire for general economy is routinely sublimated into utilitarian behaviors, the lure of the video games has to be understood as, in part, related to their sheer unproductivity. Put more simply, our unrestricted play is constantly being channeled into goal-directed games; how appealing then to find a game whose essence seems to be totally useless play (Bernstein 1991)

Drawing in part from anthropological studies of pre-industrial economies, notably Marcel Mauss' theories of North American potlatch and other 'gift' economies (Mauss 2001 (1925]), the ubiquitous practices of sacrifice, and early modern cultural phenomena such as the European carnival, Bataille posited an anthropology in which pre-capitalist human society, rather than living hand to mouth in an environment of natural scarcity, has often generated significant resources and wealth. This accumulation of materials, artefacts, livestock, etc. constitutes an excess that must be dealt with in some way - expended. Bataille argued that this expenditure of excess wealth is generally conducted through spectacular rituals, including sacrifices of goods, animals, even humans. For Bataille then the mainstream economic theories of the modern era, predicated on the assumption of limited resources, are upside down. Human culture and society has in the main been amply provided for in terms of natural resources, stemming in the first instance from the infinite energy source of the sunii. Sacrifice and gift rituals were primarily the expenditure of accumulated wealth and resources, an inevitable excess in any more or less settled human culture - a 'general' economy (Bataille 1991 [1949]).

Capitalism's 'restricted' economy does not eradicate this excess, it invests it. However something of the 'accursed share', this non-recuperable part of the economy, escapes this productive reinvestment, thus luxury goods, modern spectacle and violence and so on are the persistence of this universal dynamic. For all its instrumentalism and morality of productive activity, capitalism 
does not eradicate the wasteful and the sacred in the late modern world. The journal Documents, edited by Bataille and fellow dissident surrealists in the late 1920s, captured these fundamental dimensions of human culture and economy in photographs and commercial ephemera, from film posters and flea markets to photographs of abbatoirs and placed them alongside images of African and Oceanic tribal art.

Bataille's work has received little attention from game studies (Fuchs 2014 is a notable exception), which is perhaps surprising given his centrality to the dissemination and development of key concepts such as the distinction between work and play, gift economies, festivals and ritual, and his direct influence on game studies through his collaboration with Roger Caillois. Caillois was a member of Bataille's Collège de Sociologie and his theories of play and games are continuous with the Collège's fascination with the sacred and ritual (Caillois 2001 [1958]). This post-surrealist, postMarxist, and anthropologically-inclined milieu would also prove influential in post-war French thought that is more closely referenced by game studies, from Henri Lefebvre and Michel de Certeau to the Situationist International, Jean-François Lyotard and Jean Baudrillard, all of whom in one way or another extend the Marxist analysis of capitalism to factor in the libidinal forces of sexuality, excess, play, the artificial and the everyday (see Giddings 2007).

\section{Rules, restrictions, and plenitude}

Bernstein saw in the code-driven worlds of early videogames a microcosmic playing out of the dynamics of Bataille's restricted and general economies. As virtual objects, environments and characters can be repeatedly reproduced and distributed within a game at no cost in the conventional senseiii, games are a 'medium characterized by plenitude' (Bernstein 1991). Digital and network culture at large is similarly characterised of course, and it has often been noted that the digital cultural economy is fundamentally unrestricted in key aspects: digital artefacts from 
texts, images, music files to game objects can be reproduced and distributed with next to zero cost. Media companies have worked hard to develop and impose technical and legal fixes to this (e.g. the prosecution of Napster in 2000, or digital rights management technology), but the underlying principle of limitless resources and instantaneous transfer pertains. To function as challenging games however and not some virtual cornucopia of unlimited items and vistas, videogame design must impose restrictions on these worlds' production of and access to such resources. As Bernstein puts it, they must 'create an artificial economy of scarcity' (Bernstein 1991). The control of the supply of ammunition, 'health', currency, and so on is central in establishing the challenges of a game, the 'restricted' economy here is primarily for ludic ends.

Within games studies these 'restrictions' are more usually understood as 'rules', aspects of the game world that limit or direct the movement, abilities, temporality, etc. of the player and avatar, yet from the perspective I am developing here they are often fundamentally economic in operation and effects. So, resources such as health, ammunition, in-game currency and so on could just as easily, or more easily, be programmed as infinite in their availability. Resident Evil with unlimited supplies of ammunition would be a very different play experience. A plentiful supply of Colour Bombs in Candy Crush would remove the core challenge and pleasure of the game. Digital game design is in large part a balancing of the immanent general economy of infinite digital artefact production with restrictions that shape and structure challenge, competition and sociality. On one important level then, an endogenous game economy is limited for purely ludic reasons: to scaffold agonistic or cooperative play, to slow down progress through the game, to provide intellectual challenges and temporal blocks. As Edward Castranova put it in relation to the endogenous economics of MMOs: 
in a normal market the demanders are willing to pay money to have constraints removed, but in a games market they will pay money to have constraints imposed [...] The puzzle of puzzles is that the demand for a good can rise when a constraint becomes tighter (Castranova 2003).

At the very least, digital gameworlds invert the logic of supply and demand in the wider capitalist economy.

The SimCity and The Sims series of games offer a different articulation of restriction and general excess that transcends both their diegetic economies (the simulation of accumulation, investment and expenditure in the former; work, time and domestic consumption in the latter) and their putative game mechanic. This tension runs through critical responses to the games. For some (as we have seen), the games are underpinned by consumer capitalist or neoliberal models that restricts radical alternative socio-economic experimentation. More often they are held up as exemplars of a less restricted game design, offering players open-ended and emergent approaches to their goals or play pleasures. Whilst it might be possible to study the extent to which SimCity players experiment with - or run up against - the games' underlying socio-economic models of economy, growth and development, the expanded notion of ludic economy I am developing here suggests a wider view. Attention to the everyday, lived environments and behaviours of gameplay provides hints of the disruptive drive of a virtual general economy, partly in that sense of wasteful, pleasurable behaviour that attends all videogame play noted above, and more particularly in the widely known cheats that allow players to effectively remove key restrictions. A famous example of this is the 'motherlode' cheat in The Sims: a code that prompts the gameworld to generate large amounts of virtual currency, a sudden removal of restrictions on supply, and the eradication of 
scarcity: a plenitude that frees the player to pursue play styles less fettered by the artificial economy.

Significantly, both Fiske \& Watts and Bernstein make reference to Roland Barthes' 1950s account of Japanese players of pachinko. For Barthes, pachinko - a mechanical arcade game, somewhere between pinball, bagatelle and the fruit machine - and its players are at once an allegory of, and palliative for, wage labour under advanced capitalism. The players lined up at their machines are (again) redolent of the assembly line, whilst the mechanics and playing of this game are explicable as remedial microcosm of the lived experience of restricted capitalist economies, but one that holds out the promise of, however rarely and briefly, a 'general economy' eruption of excess from the mechanically-regulated restricted system of coins and rewards:

the player, with an abrupt gesture... feeds the machine with his metal marbles; he stuffs them in... from time to time the machine, filled to capacity, releases its diarrhea of marbles; for a few yen, the player is symbolically spattered with money. Here we understand the seriousness of a game which counters the constipated parsimony of salaries, the constriction of capitalist wealth, with the voluptuous debacle of silver balls, which, all of a sudden, fill the player's hand (Barthes 1982: 28).

Constipation, constraint and work-like attention to the machine - but with moments of sudden voluptuous release and reward, the mechanisms of restricted and general economies are played out and through arcade machines and players' bodies and desires. There are clear connections here with the Western fruit machine and its promise of plenty from complicated and systematised mechanisms, and this play between aleatory restriction and semiotic and experiential excess is evident in contemporary digital games, not least 'free to play' mobile games. Candy Crush for 
instance is a simulated orgy of consumption - the player sees hundreds of sweets consumed every time he or she plays. That they don't actually eat or taste the sweets is compensated for in the visual plenitude or excess of their appearance and animated disappearance, in their vivid colours and the glistening almost tactile sheen of their surfaces and wrappers, and in the voluptuous feedback loops of generation, transformation and annihilation of virtual goods. Like pachinko and fruit machines there is a system of equivalence and value, and a mechanical balance between random fate (the vagaries of physics in pachinko, the algorithmic distribution and alignment of tokens in fruit machines and Candy Crush), but these devices of the games' restricted economy only make sense only make pleasure - when nested within the general potential or trajectories of players' bodily engagement, ludic attitudes and - perhaps - libidinal economic investment (see also Harvey, this issue).

\section{Grotesque economies}

These articles from the prehistory of game studies offer tantalising ideas about the very new relationships between videogame worlds, the practices of their playing, and the global economy of production and consumption. They are sensitive to the peculiar artifice of computer games, their rule-based abstraction and more complicated, metamorphic relays between virtual and actual worlds, intriguing resonances between game mechanics and wider economies, and between the pleasures of videogame play and subjective formations at the end of the twentieth century. Videogames appear now as a microcosmic articulation of the restricted economy and the general economy: the general economy is not consigned to a pre-industrial past, rather it persists in and underpins late capitalism. A key implication here is that the 'restrictions' of a capitalist economy are not determined by limits on natural and social resources, but by game-like systems of behaviour, value and artificial restrictions. 
In itself this dimension of digital games is a significant inversion. It doesn't 'represent' the restricted economies of late capitalism, rather it turns them on their head. Laws of nature and market forces (the two indistinguishable under neoliberal orthodoxy) are rendered arbitrary, manipulable, float free of any material grounding and offer themselves up for pleasure. So to play with games and objects is to manipulate, to shake, to open up, as well as to abide by and reproduce the rules, rules that can be more fruitfully considered as ludically-determined relationships of value, exchange, scarcity and plenitude. Conversely though, in its facilitation of play and playful sociality, endogenous virtual restriction serves the ends of an exogenous accumulation. It is too simple to say that videogame culture's wasteful pleasures and excessive imagery are either straightforwardly subversive of capitalist work culture, or that they merely serve it, training body, mind and sense of self for ideal consumption and production. Rather, we can see the articulations, negotiations, contradictions and persistent prehistories of consumer capitalism played out in different and contradictory ways in different games. The Sims' ostensibly banal domestic consumption can generate carnivalesque nonsense, whereas the virtual fantasy of World of Warcraft also re-inscribes material restrictions of economic and geographic class through the labour of gold-farming.

There are echoes here then of Stallabrass' invocation of phantasmagorical allegory. However, if we accept that game economies in games are stranger than they first appear, then once embedded in everyday life a different notion of phantasmagoria emerges. As an artistic or media form, allegory tends to manifest itself as an aesthetic or playful moving away from its putative source system over time rather than rigidly and persistently articulating it. At the very least, as Fiske and Watts noted, game behaviour and culture is prone to varying degrees of inversion and reversal in symbolism, significance and effects. Via game studies' work on gift economies (Giddings 2014a), the carnivalesque, dark play (Mortensen et al, 2015), the aesthetics of the grotesque (Klevjer 2006), 
and Brian Sutton-Smith's rhetoric of play as phantasmagorical (1997) we find a resonance with a Bataillean anthropology and economics of the excessive, the sacred and the phantasmagorical.

\section{Conclusion: towards a general ludic economy}

The prehistory of game studies reminds the contemporary game scholar of the persistent novelty and strangeness of the videogame as a dynamic economic form. These diverse texts from the end of the twentieth century draw out ambiguous yet compelling relationships between the endogenous economies of game software and virtual worlds and the exogenous flows of investment, exchange, and accumulation of the late capitalist cultural and technological economy from which games issue and to which they contribute. As such they can contribute to contemporary investigation of the modes of exchange, value and accumulation that are integral to the new ludic economies of mobile, multiplayer and co-created digital games - and hence too of the worlds of consumer and technological capitalism, neoliberal subjectivity and everyday media consumption within which they circulate. They have a potential role too in the imagining and designing of new game systems, models and critical theories that can articulate explore play with alternative systems of exchange and value. Understanding games and play as in themselves economies, as systems of drives and exchange, leads in one direction to a closed notion of simulacral ideology isomorphic with neoliberal subjecthood, but in another towards the phantasmagorical in a generative sense - as metamorphic, emergent, wasteful and excessive, and hence as a seedbed for new formations and resources for behaving and imagining differently within and against the prevailing cultural and political economy. 


\section{Works Cited}

Alvisi, A. (2006). The economics of digital games. In Rutter, J. \& Bryce, J. (eds) Understanding digital games. London: Sage. 58-74.

Barthes, R. (1982). Empire of signs. New York NY: Noonday Press.

Bataille, G. (1991 [1949]). The accursed share. Volume I. Cambridge MA: Zone Books.

Bernstein, C. (1991). Play it again, Pac-Man. Postmodern Culture, 2(1).

http://pmc.iath.virginia.edu/text-only/issue.991/pop-cult.991

Caillois, R. (2001 [1958]). Man, Play and Games. New York: The Free Press.

Castronova, E. (2003). On virtual economies. Game Studies 3(2).

http://www.gamestudies.org/0302/castronova/

Dyer-Witheford, N. and de Peuter, G. (2009). Games of empire: Global capitalism and video games. Minneapolis: Minnesota University Press.

Fiske, J. \& Watts, J. (1985). Video games: Inverted pleasures. Australian Journal of Cultural Studies 3(1). Online at: https://www.mcc.murdoch.edu.au/ReadingRoom/serial/AJCS/3.1/Fiske.html

Frissen, V., Lammes, S., de Lange, M., de Mul, J. and Raessens, J. (2015). Playful identities: The ludification of digital cultures. Amsterdam: University of Amsterdam Press.

Fuchs, M. (2014). Ludoarchaeology. Games and Culture 9(6). 528-538.

Fuchs, M., Fizek, S., Ruffino, P, and Schrape, N. (eds) (2014). Rethinking gamification. Lüneberg: meson press.

Giddings, S. (2007). A 'pataphysics engine: Technology, play and realities. Games and Culture 2(4). 392-404.

Giddings, S. (2014a). Gameworlds: Virtual media and children's everyday play. New York: Bloomsbury. 
Giddings, S. (2014b). 'Simulation'. In M. J.P. Wolf \& B. Perron (eds). The Routledge companion to video game studies. New York: Routledge. 259-266.

Giddings, S. \& Kennedy, H.W. (2006). Digital games as new media. In J.Rutter \& J.Bryce (eds).

Understanding digital games. London: Sage. 129-147.

Goggin, J. (2009). 'Fantasy and finance: Play money and computer game culture', in K.S. McAllister \& J.R. Chaney (eds) The Computer game culturerReader, Cambridge: Cambridge Scholars Press. 125137.

Harvey, A. (in press). 'The fame game: working your way up the celebrity ladder in Kim Kardashian: Hollywood'. Games \& Culture.

Ito, M. (1996). 'Uses and subversions of SimCity $2000^{\mathrm{TM}}$, http://www.itofisher.com/PEOPLE/mito/Ito.4S96.pdf

Kerr, A. (2005). The Business and culture of digital games: gamework and gameplay. London: Sage. Kerr, A. (2016). Global games: Production, circulation and policy in the networked era. New York: Routledge.

Klevjer, Rune. (2006). Dancing with the modern grotesque: War, work, play and ritual in the runand-gun first person shooter. http://folk.uib.no/smkrk/docs/dancing.htm

Kline, S., Dyer-Witheford, N. \& de Peuter, G. (2003). Digital play: The interaction of technology, culture, and marketing. Montreal: McGill-Queen's University Press.

Kocurek, C. (2012). 'Coin-drop capitalism: Economic lessons from the video game arcade', in M.J.P. Wolf (ed.) Before the Crash: early video game history. Detroit MI: Wayne State University Press. 189208.

Marx, K. (1990 [1867]). Capital: Critique of political economy. Vol.1. Harmondsworth: Penguin Classics.

Mauss, M. (2001 [1925]). The gift: Forms and functions of exchange in archaic societies. London:Routledge. 
Mortensen, T.E., Linderoth, J., and Brown, A.M.L. (2015). The dark side of play: Controversial issues in playful environments. London: Routledge.

Nieborg, D. (2015). 'From premium to freemium: the political economy of the app', in T. Leaver \& M. Wilson (eds) Social, casual and mobile Games: The changing gaming landscape. New York: Bloomsbury: 225-240.

Penny, S. (2004). 'Representation, enaction, and the ethics of simulation'. First Person 2004-06-26. http://www.electronicbookreview.com/thread/firstperson/machanimate

Poole, S. (2001). Trigger Happy: the inner life of videogames. London: Fourth Estate.

Shaw, A. (2014). Gaming at the edge: sexuality and gender at the margins of gamer culture. Minneapolis: University of Minnesota Presss.

Stallabrass, J. (1993). Just gaming: Allegory and economy in computer games. New Left Review 198. http://newleftreview.org/I/198/julian-stallabrass-just-gaming-allegory-and-economy-incomputer-games

Stevens, R., Satwicz, T. and McCarthy, L. (2008). 'In-game, in-roon, in-world: reconnecting videg game play to the rest of kids' lives'. In K. Salen (ed.) The Ecology of Games: connecting youth, games, and learning. Cambridge MA: MIT Press, 41-66.

Sutton Smith, B. (1997). The ambiguity of play. Cambridge MA: Harvard University Press. Taylor, T.L. (2006). Play between worlds: Exploring online game culture. Cambridge MA: MIT Press. Wark, M. (2013). A ludic century?" Public Seminar Commons. Available online at: http://www.publicseminar.org/2013/11/a-ludic-century/\#.U6qDjrGTG8p Zimmerman, E. and Chaplin, H. (2013). Manifesto: The $21^{\text {st }}$ century will be defined by games. Online at https://www.kotaku.com/manifesto-the-21st-century-will-be-defined-by-games-1275355204 
${ }^{i}$ For a contemporaneous assessment of the behavioural operations of simulation as training, see also Simon Penny (2004).

ii It is important to note that Bataille was not assuming some golden age of plenty for all. The wealth of civilizations from pre-Columbian America back to Antiquity was by no means equitably distributed, indeed we might regard the slaves, indentured labour (and candidates for human sacrifice) as a significant component of the environment and resources from which the elite extracted this excessive value.

iii There is of course a techno-economic infrastructure of computer memory, storage and speed that underpins this virtual plenitude. Recently a number of media scholars have demonstrated that digital worlds do of course have profound material-economic consequences. From the energy demands of server farms to the mining and recycling of rare earth minerals, digital culture is material culture. However, once this infrastructure and its actual effects are acknowledged, the reproduction and distribution of virtual objects is in itself virtually infinite. 